\title{
Improved Water Management Strategies for Chennai Metropolitan Area
}

\author{
Jeppiaar', Radhakrishnan $\mathbf{R}^{2}$, Manoharan $\mathbf{N}^{3}$ \\ ${ }^{1}$ Chancellor, Sathyabama University, Chennai \\ ${ }^{2} V$ ice-Chancellor, Anna University, Coimbatore \\ ${ }^{3}$ Dean (PG Studies \& Research), Sathyabama University, Chennai \\ e-mail: jeppiaar_sathya@yahoo.com
}

\begin{abstract}
Water is needed in all aspects of life. The general objective is to make certain that adequate supply of water of good quality is maintained for- the entire population, while preserving the hydrological, biological and chemical functions of ecosystem. Innovative technologies are needed to fully utilize the limited water resources. The challenge of meeting the drinking water requirement of such huge population in addition to the other water requirements needs immediate steps to be taken.
\end{abstract}

Key words: Remote Sensing, Geometric Increase Method,

\section{INTRODUCTION}

The existing status of water supply, characteristics of domestic wastewater, modes of collection, treatment and disposal system for sewage in 82 municipalities and 4 municipal corporations were assessed in the states of Bihar and West Bengal in India (Pandey 2000). The Central Ground Water Board (2002) had taken up a project of artificial recharge of groundwater in the Jawaharlal Nehru University (JNU), Delhi and in the Indian Institute of Technology (IIT), Delhi. To harness the available runoff, three check-dams were constructed in JNU and one check-dam in the IIT campus. Latha (2004) studied the potential of reuse of wastewater for meeting the supplydemand gap. The study found out that reused water could meet $66 \%$ of the present demand. The study carried out by Anu et al. (2005) deals with the effects of the increase in population on to the groundwater table, especially, in the city due to its urbanization. The objectives of this study are to study the domestic water supply and demand scenario of Chennai Metropolitan Area from the year 1981 onwards to the present status and the water demand for the future and to suggest management strategies to reduce the gap between supply and demand and also to provide improved distribution of domestic water for Chennai Metropolitan Area.

\section{STUDY AREA}

Chennai Metropolitan Area (CMA) situated in the north eastern end of Tamil Nadu on the coast of Bay of Bengal is chosen for the present study. It extends over an area of $1172 \mathrm{~km}^{2}$ having a population of 66 lakhs in 2001 . The average annual rainfall for Chennai Metropolitan Area is $1200 \mathrm{~mm}$. The rainfall pattern of CMA from the year 1971 to 1999 is shown in fig.1.There is no perennial water source available for Chennai Metropolitan Area.

\section{DATA COLLECTION}

The data was collected pertaining to river basins, existing water bodies, groundwater availability, rainfall, present water distribution system and population. The population data required for the study is collected from Directorate of Census Operations, Chennai, Tamil Nadu. To focus on the efficient management of the water supply, sectorial classification of the Chennai Metropolitan Area is designed. The various factors that affect the water supply are identified and proper techniques are selected for their analysis. The various techniques used for the analysis are Population projection, Demand Assessment and Runoff Estimation and are shown below.

\section{METHODOLOGY}

The Geometric Increase Method is used in this study to forecast the population. The total water demand for the CMA is calculated as Total Water Demand $=$ Design Population x Per Capita Demand. The per capita demand is based on the norms given by the Tamil Nadu Water Supply and Drainage Board (TWAD Board). According to it, for corporation areas 110 litres per capita per day, municipalities 90 litres per capita per day and for town panchayats 70 litres per capita per day is required. The runoff (yield) is determined using Yield $=$ Area $x$ Runoff Coefficient $x$ Average Annual Rainfall where, runoff coefficient $=0.15$ for CMA (Institute for Water Studies 1994).

Remote Sensing data of LANDSAT ETM + available on the website www.glcfapp.umiacs.umd.edu: 8080/esdi/index.jsp on June 28, 2002 having $30 \mathrm{~m} \times 30 \mathrm{~m}$ resolution along with the Survey of India toposheets $66 \mathrm{C} 4$, $66 \mathrm{C} 8,66 \mathrm{D} 1,66 \mathrm{D} 5$ was used to extract the base map for CMA, the study area have been constructed using Arc View 3.2a software. For the present study, an improved 
water management strategy over the existing system is proposed which divides the Chennai Metropolitan Area into interconnected and independent sectors. The Chennai

Metropolitan Area is divided into 4 sectors as North sector, Central sector, South sector and West sector. The settlement categories of each sector identified from the village boundary layer and the population is found out. The main factors that were considered for the sectorial classification of Chennai Metropolitan Area includes proximity of water sources in each sector, water potential and its effective storage in each sector, increasing demand due to the urban development in each sector, land use pattern of the area, optimum distribution of the available water to each sector, to maintain the quality of water supply and improvement of the existing water supply system taking into account the high cost, difficulties in transportation from far off sources, social and political influences. The settlement categories of each sector identified from the village boundary layer and the population is found out. The digitized map overlaying the village boundary and sectorial boundary is shown in fig.3. Based on the estimated population for each sector, the demand calculation is carried out. The rainfall data and the areal extend of each sectors were used to estimate the runoff. Thus each sector can be made self sufficient to meet its own water demand. This will help in the equitable distribution of water throughout the sectors.

\section{RESULT AND ANALYSIS}

The census data for the years 1981, 1991 and 2001 were collected and the Chennai Metropolitan Area's future population is forecasted using geometrical increase method. It is found to be 137.5 lakhs for the year 2025 . Fig.2 shows the growth of population in the Chennai Metropolitan Area for a period of 2001 to 2025. The increase of water demand for the respective years is shown in Fig.3. In CMA, for the year 2025, for the population of 137.5 lakhs, the total requirement of water will be of the order of 1292 MLD.

\section{A. Analysis of North Sector}

The forecasted population and water demand for the north sector is shown in Table 1. For the year 2025, the population is forecasted as 28 lakhs and the water demand is $278 \mathrm{MLD}$. The study revealed that the potential benefits of using Araniar - Kosasthaliar Basin aquifers to augment water supply to Chennai are huge. A system to abstract, harness and supply water to the north sector can be made available by drilling additional well fields in the Araniar Kosasthaliar Basin. This water can be stored treated and distributed in this sector itself. A water treatment plant of capacity $300 \mathrm{MLD}$ is recommended to be constructed at Ponneri against a total water requirement of $278 \mathrm{MLD}$ in the year 2025. The surplus water of Araniar Kosasthaliar basin is 28 MCM (76 MLD) (Institute for Water Studies) that can be stored in the proposed reservoir in the Araniar Kosasthalaiyar Basin. The surface runoff of north sector is estimated as 43.95 MCM (120 MLD) can be stored in storage structures. The additional wellfields can provide $30 \mathrm{MCM}$ (82 MLD) to meet the requirement. This water can be brought to the water treatment plant at Ponneri, where it is treated and distributed to various parts of the north sector. This will improve the existing infrastructure of water supply system in the north sector.

\section{B. Analysis of Central Sector}

The forecasted population and water demand for the central sector are shown in Table 2. In the central sector, for the year 2025, the population is forecasted as 60 lakhs and the water demand is 595 MLD. According to the sectorial classification, the water from Kilpauk water works is to be used for the central sector alone. The present capacity of Kilpauk water works is $327 \mathrm{MLD}$. In this sector, both the surface and groundwater comprises 315 MLD. Apart from these, nearly $100 \mathrm{MLD}$ of water comes from the stormwater runoff can be stored in recharge structures. About 30 MLD can be taken from the tanks and lakes. To meet out the gap, a system to abstract, harness and supply the groundwater from the A-K basin well fields that has an availability of 1783 MLD can be planned. This can be achieved by drilling additional well fields in the AraniarKosasthalaiyar Basin by conducting appropriate hydrogeological investigations. Therefore, additional water of $80 \mathrm{MLD}$ can be tapped from newly proposed wellfields in Araniar Kosasthalayar Basin so as to meet the demand satisfactorily.

\section{Analysis of South Sector}

The forecasted population and water demand for the south sector are shown in Table 3. For the south sector, $258 \mathrm{MLD}$ of water is required for a predicted population of 3248235 for the year 2025. River Palar supplement 9.16 MCM (25 MLD) of water to the peri urban areas of CMA. The water from the Veeranam Project can be diverted to the south sector, that can supply 66 MCM (180 MLD) of water. The runoff is estimated as 54.65 MCM (150 MLD) that can be stored in storage structures and can be used for south sector. The excess runoff from the adjacent areas of the tanks and lakes can be diverted to it that will improve the groundwater status of this sector. water can be supplied to the south sector by constructing two water treatment plants each of capacity 100 MLD. One water treatment plant can be placed at Oggiyamduraipakkam 
and another at Tambaram where provisions can be made to collect, store, treat and distribute water to cater the needs of the south sector.

\section{Analysis of West Sector}

The forecasted population and water demand for the west sector are shown in Table 4. In the west sector, for the year 2025, the population is forecasted as 17 lakhs and the water demand is 161 MLD. From Telugu Ganga Project, by mutual agreement, 12 TMC (8 TMC of water during July to October and 4 TMC of water during January to April every year) of water has to be delivered to Poondi reservoir in Tamil Nadu.

Presently only 3 TMC (229 MLD) of water is given that augments the water supply to Chennai. This water has to be used to meet the demands of west sector. The Chembarambakkam Lake, lying in the west sector, having a storagecapacityof 103.2 MCM (282 MLD) can supplement water to west sector. The runoff of this sector is about $23.36 \mathrm{MCM}$ (64 MLD) can be stored in a storage structure. A water treament plant of capacity 180 MLD can be constructed at Porur for the west sector.

A detailed analysis of the existing water demand and supply of the Chennai Metropolitan reveals that total requirement of the Chennai Metropolitan Area will be of the order of 1292 MLD for a population of 137.5 lakhs in the year 2025. To augment the water supply and to efficiently manage the available water sources, the Chennai Metropolitan Area is classified into four sectors

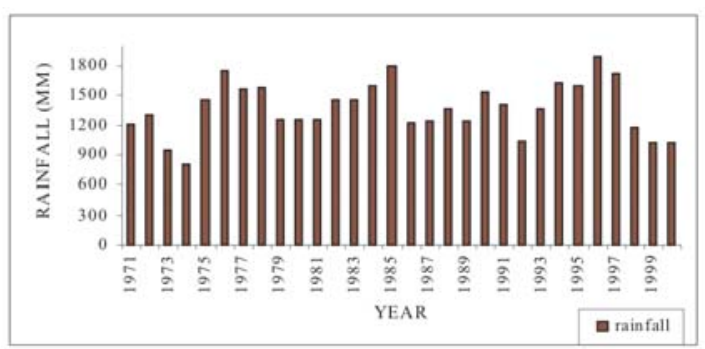

Fig. 1. Rainfall Pattern of CMA

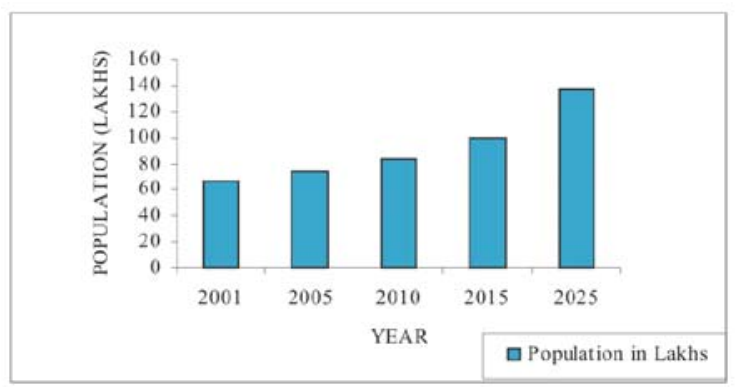

Fig. 2. Population details of $\mathrm{CMA}$

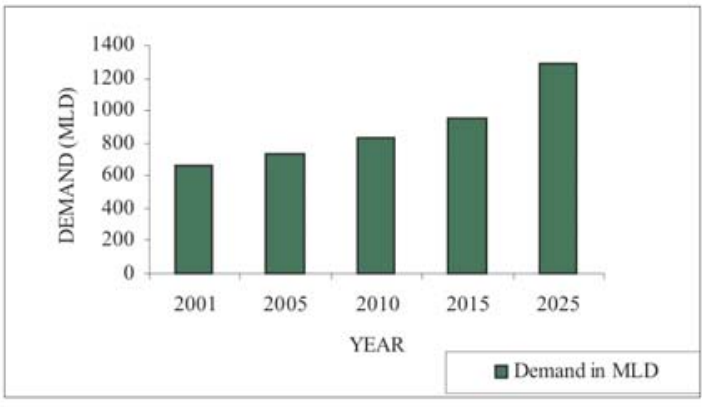

Fig. 3. Water Demand of CMA

Table 1. Population And Demand For North Sector

\begin{tabular}{|c|c|c|}
\hline Year & $\begin{array}{c}\text { Population } \\
\text { (Lakhs) }\end{array}$ & $\begin{array}{c}\text { Demand } \\
\text { (MLD) }\end{array}$ \\
\hline 2001 & 17 & 177 \\
\hline 2005 & 19 & 191 \\
\hline 2010 & 20 & 208 \\
\hline 2015 & 23 & 229 \\
\hline 2025 & 28 & 278 \\
\hline
\end{tabular}

Table 2. Population and Demand for Central Sector

\begin{tabular}{|c|c|c|}
\hline Year & $\begin{array}{c}\text { Population } \\
\text { (Lakhs) }\end{array}$ & $\begin{array}{c}\text { Demand } \\
\text { (MLD) }\end{array}$ \\
\hline 2001 & 31 & 325 \\
\hline 2005 & 34 & 357 \\
\hline 2010 & 39 & 397 \\
\hline 2015 & 45 & 457 \\
\hline 2025 & 60 & 595 \\
\hline
\end{tabular}

Table 3. Population and Demand for South Sector

\begin{tabular}{|c|c|c|}
\hline Year & $\begin{array}{c}\text { Population } \\
\text { (Lakhs) }\end{array}$ & $\begin{array}{c}\text { Demand } \\
\text { (MLD) }\end{array}$ \\
\hline 2001 & 10 & 89 \\
\hline 2005 & 12 & 105 \\
\hline 2010 & 15 & 126 \\
\hline 2015 & 19 & 129 \\
\hline 2025 & 32 & 258 \\
\hline
\end{tabular}


Table 4. Population and Demand for West Sector

\begin{tabular}{|c|c|c|}
\hline Year & $\begin{array}{c}\text { Population } \\
\text { (Lakhs) }\end{array}$ & $\begin{array}{c}\text { Demand } \\
\text { (MLD) }\end{array}$ \\
\hline 2001 & 8 & 77 \\
\hline 2005 & 9 & 86 \\
\hline 2010 & 10 & 98 \\
\hline 2015 & 12 & 115 \\
\hline 2025 & 17 & 161 \\
\hline
\end{tabular}

\section{REFERENCES}

[1] Anu, D., Maharajan, N., Bharanidharan, $H$. and Satheesh, 2005, P. (2005). Urbanisation effects on Ground Water Table. $8^{\text {th }}$ Annual International Conference, Geomatics, Map India.
[2] Central Groundwater Board (2002-2007). Civic Amenities in Urban Areas, Tenth Five Year Plan, pp. 633-659.

[3] Latha, N., Deepa, N. and Anand B.K. (2004). Wastewater Reuse in Mega cities - Emerging Trends in Bangalore City, Institute for Social and Economic Change, Bangalore.

[4] Pandey, R.A. and Kaul, S.N. (2000). Status of Domestic Wastewater in Relation to Drinking Water Supply in two States of India. A Service of the National Library of Medicine and National Institutes of Health, pp 405-411. 